\title{
Effect of Hydrolysis Temperature on in vitro Bioaccessibility and Antioxidant Properties of Unicorn Leather Jacket (Aluterus monoceros) Skin Collagen Hydrolysates Following Simulated Gastro-Intestinal Digestion
}

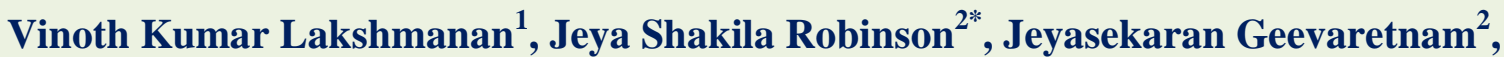 Velayutham Padmanaban ${ }^{1}$ and Wenhui $\mathrm{Wu}^{3}$}

${ }^{1}$ Department of Fish Processing Technology, Fisheries College and Research Institute, Tamil Nadu Dr. J. Jayalalithaa Fisheries University, Tuticorin 628 008, India

${ }^{2}$ Department of Fish Quality Assurance and Management, Fisheries College and Research Institute, Tamil Nadu Dr. J. Jayalalithaa Fisheries University, Tuticorin 628 008, India

${ }^{3}$ Controller of Examinations, Tamil Nadu Dr. J. Jayalalithaa Fisheries University, Nagapattinam, India

*Corresponding author

\section{A B S T R A C T}

The aim of the research was to prepare collagen hydrolysate $(\mathrm{CH})$ from unicorn leatherjacket (Aluterus monoceros) fish skin using papain at different hydrolysis

\section{Keywords}

Unicorn leatherjacket, Collagen hydrolysates, Hydrolysis temperature,

Simulated gastro intestinal digestion, Bioaccessibility, Biofunctionality

Article Info

Accepted:

28 October 2017

Available Online:

10 December 2017 temperature viz. $5^{\circ} \mathrm{C}(\mathrm{CH}-5), 20^{\circ} \mathrm{C}(\mathrm{CH}-20), 25^{\circ} \mathrm{C}(\mathrm{CH}-25)$ and $50^{\circ} \mathrm{C}(\mathrm{CH}-50)$ and to investigate the antioxidant properties (DPPH free radical-scavenging activity, ferric reducing power assay, ferric chelating activity and hydroxyl radical scavenging activity) prior to and after in vitro gastrointestinal (pepsin-pancreatin) simulated digestion in order to assess the bioaccessibility and biofunctional activities. The DH was higher $(4.27 \%)$ for CH-50 within 300 min of hydrolysis than other CH's. On contrary, ferric reducing and ferric chelating properties were comparatively higher in CH-5 than other CH's, corresponding to $33 \%$ and 0.32 absorbance units, respectively at $8 \mathrm{mg} / \mathrm{mL}$ protein concentration. DPPH free radical-scavenging and hydroxyl radical scavenging activities were more or less similar in all CH's. Subsequent in vitro gastrointestinal simulated digestion studies showed that the bioaccessibility of $\mathrm{CH}-50$ was higher (54.25) after gastric and pancreatic digestion, but $\mathrm{CH}-5$ exhibited good antioxidative property expressing $90 \%$ activity. FTIR spectral analysis further confirmed it through expression of major shifts in amide A, I and II peaks and disappearance of aromatic ring peaks in $\mathrm{CH}-5$. The study thus indicated that $\mathrm{CH}$ with good antioxidant activity shall be produced by hydrolysis the skin at $5^{\circ} \mathrm{C}$, rather than at $50^{\circ} \mathrm{C}$.

\section{Introduction}

Collagen is the predominant protein of connective tissue in animals, making up about $30 \%$ of the total protein. It has a wide range of application in pharmaceutical and biomedical industries, which include tissue engineering for implants in humans, inhibition of angiogenic diseases, treatment of hypertension, urinary incontinence and osteoarthritis (Lee et al., 2001). The main sources of industrial collagen are those from pig and bovine skin and bones. The outbreaks of Bovine Spongiform Encephalopathy, Foot 
and Mouth disease and certain religious concern have resulted in causing restriction on animal collagen trade. On the other hand, marine collagen obtained from skins, bones, scales, as well as swim bladder of fish turned out as a better alternative. Collagen hydrolysate is a polypeptide made by hydrolysis of denatured collagen (GomezGuillen et al., 2002). Collagen is enzymatically hydrolysed by a process employing commercially available proteolytic enzymes to liberate physiologically active peptides. By selection of suitable enzymes and controlling the conditions, the properties of the end product can be modified. Many studies have been conducted to extract and screen the potential bioactive properties of collagen hydrolysates from fish by products, such as gaint squid skin (Dosidicus gigas) (Alemán et al., 2013), Croceine croaker scale (Pseudosciaena crocea) (Wang et al., 2013), Spanish mackerel skin (Scomberomorous niphonius) (Chi et al., 2014), and so on. Some collagen derived peptides exhibit good antioxidant activity, potent anti-hypertensive activity, anti-microbial activity against different strains of bacteria, protective effect on cartilage, or capacity to stimulate bone formation.

Unicorn leatherjacket (Aluterus monoceros) belonging to the order, Tetradontiformes and family, Monacanthidae, is a fish mainly used for fillet production and hence, large amounts of skin are discarded as wastes. The thick skin of the leatherjacket is a potential source for the production of fish collagen. In many of the previous studies, collagen hydrolysates are derived from the source raw material upon hydrolysis using suitable enzyme at $50^{\circ} \mathrm{C}$. It is known that fish collagen denatures to gelatin at $40-50^{\circ} \mathrm{C}$ due to loss of their 3-dimensional structure. Formation of collagen hydrolysates at $50^{\circ} \mathrm{C}$ is therefore expected to produce peptides with structural conformation similar to gelatin rather than collagen; exhibiting low biological functions. In order to understand the bioactive properties of collagen hydrolysates prepared at different hydrolysis temperature, this study was undertaken to examine their in-vitro antioxidant property prior to and after in-vitro gastro intestinal digestion.

\section{Materials and Methods}

\section{Raw materials}

Unicorn leatherjacket (Aluterus monoceros) belonging to the family, Monacanthidae is an important fishery in the East Coast of India. The flesh of the fish is edible, while the tough skin is discarded as wastes during fillet processing. Skins were procured from Sumaraj Seafoods Pvt Ltd, Mangalore, India; brought to the laboratory in iced condition and held at $-20^{\circ} \mathrm{C}$ until further analysis.

\section{Extraction of collagen hydrolysates}

Skins were thawed in runned water and chopped into small pieces prior to treatment with $0.8 \mathrm{~N}$ sodium chloride $(\mathrm{NaCl})$ at a ratio of $1: 6(\mathrm{w} / \mathrm{v})$ for $10 \mathrm{~min}$ at $5^{0} \mathrm{C}$ to remove the impurities (Montero et al., 1995). This process was repeated 3 times and the skins were washed again with cold distilled water. They were then treated with $0.1 \mathrm{~N}$ sodium hydroxide $(\mathrm{NaOH})$ at a ratio of $1: 10$ for 3 days at $5^{0} \mathrm{C}$ to remove the non-collagenous proteins and to prevent the effect of endogenous proteases on collagen (Sato et al., 1986). The alkali solution was changed every day and the skins were washed with cold distilled water. They were then treated with $0.5 \mathrm{~N}$ acetic acid at a ratio of 1:6 for $30 \mathrm{~min}$ to cause swelling at $5^{0} \mathrm{C}$. The swollen skins (100 g) were homogenized with $200 \mathrm{~mL}$ of $50 \mathrm{mM}$ phosphate buffer at a ratio of $1: 2$, for $5 \mathrm{~min}$ in a pestle and mortar. The $\mathrm{pH}$ of the homogenate was adjusted to 7.0 and $1 \%$ papain was added for hydrolysis. Hydrolysis 
reaction was performed in a beaker placed in a magnetic stirrer at a constant agitation of $200 \mathrm{rpm}$ at different incubation temperatures of $5^{\circ} \mathrm{C}, 20^{\circ} \mathrm{C}, 25^{\circ} \mathrm{C}$ and $50^{\circ} \mathrm{C}$, to obtain collagen hydrolysates, $\mathrm{CH}-5, \mathrm{CH}-20, \mathrm{CH}-25$ and $\mathrm{CH}-50$, respectively.

\section{Degree of hydrolysis}

During the hydrolysis reaction, the degree of hydrolysis $(\mathrm{DH})$ was determined periodically by the method described by (Adler-Nissen, 1979). DH is defined as the percentage of peptide bonds cleaved to determine the free amino group reaction with 2, 4, 6trinitrobenzene sulfonic acid (TNBS). For the analysis, $0.25 \mathrm{~mL}$ aliquot was withdrawn at every $30 \mathrm{~min}$ time interval into $2 \mathrm{~mL}$ of $1 \%$ $\mathrm{SDS}$ and incubated at $75^{\circ} \mathrm{C}$ for $15 \mathrm{~min}$. From this, $0.25 \mathrm{~mL}$ of the sample was transferred into the test tubes containing $2 \mathrm{~mL}$ of $0.2 \mathrm{M}$ sodium phosphate buffer ( $\mathrm{pH}$ 8.2). A blank was prepared using $0.25 \mathrm{~mL}$ of $1 \%$ SDS. Then, $2 \mathrm{~mL}$ of TNBS reagent was added to all the test tubes, vortexed, covered with aluminum foil and incubated in dark at $50^{\circ} \mathrm{C}$ for $50 \mathrm{~min}$. The reaction was stopped by the addition of $4.0 \mathrm{~mL}$ of $0.1 \mathrm{~N} \mathrm{HCl}$ and cooled at room temperature for $30 \mathrm{~min}$. The absorbance was then read at $340 \mathrm{~nm}$ in a spectrophotometer. The amount of free amino group liberated was expressed as L-leucine equivalent as follows:

Degree of hydrolysis $(\mathrm{DH})(\%)=(\mathrm{Ct} / \mathrm{Co}) \mathrm{X}$ 100

Where, $\mathrm{Ct}$ is free amino groups at time ' $\mathrm{t}$ ' and Co is total amino groups of samples.

On completion of hydrolysis for $360 \mathrm{~min}$, the enzymes were inactivated by the addition of 6 $\mathrm{M} \mathrm{HCl}$. The hydrolysates were centrifuged at $13000 \mathrm{rpm}$ in a refrigerated centrifuge (Eppendorf centrifuge 5804 R, Germany) at $4^{0} \mathrm{C}$ for $10 \mathrm{~min}$. The supernatant was collected as hydrolysates and neutralized to $\mathrm{pH} 7.0$ using $1 \mathrm{~N} \mathrm{NaOH}$. The protein content of the collagen hydrolysates was estimated by the Biuret method using bovine serum albumin as standard.

\section{DPPH free radical scavenging activity}

DPPH free radical-scavenging activity was determined by the method described by (Yen and $\mathrm{Wu}, 1999)$. $\mathrm{CH}$ was diluted with distilled water to obtain a concentration of $1,2,3,4$ and $5 \mathrm{mg}$ protein $/ \mathrm{mL}$. An aliquot of $1.5 \mathrm{~mL}$ of each $\mathrm{CH}$ was added to $1.5 \mathrm{~mL}$ of $0.1 \mathrm{mM}$ $\mathrm{DPPH}$ in $99.5 \%$ ethanol and mixed thoroughly. The reaction mixture was held in a dark place for $30 \mathrm{~min}$ at room temperature. The absorbance was measured at $517 \mathrm{~nm}$ in a double beam UV-Vis spectrophotometer (Model V-530 Jasco, Japan). Distilled water was used as control.

DPPH free radical scavenging activity $(\%)=$ 1- (Abs sample / Abs control) $\times 100$

\section{Ferric reducing power assay}

The ability of hydrolysates to reduce iron (III) to iron (II) was determined by the method described by (Oyaizu, 1986). An aliquot of 1 $\mathrm{mL}$ of each $\mathrm{CH}$ containing 1, 2, 3, 4 and $5 \mathrm{mg}$ protein $/ \mathrm{mL}$ concentration was mixed with 2.5 $\mathrm{mL}$ of $0.2 \mathrm{M}$ phosphate buffer $(\mathrm{pH}$ 6.6) and $2.5 \mathrm{~mL}$ of $1 \%$ potassium ferric cyanide. The reaction mixture was incubated at $50^{\circ} \mathrm{C}$ for 30 min and the reaction was stopped by the addition of $2.5 \mathrm{~mL}$ of $10 \%$ trichloroacetic acid (TCA). From that, $2.5 \mathrm{~mL}$ solution was pipetted out and mixed with $2.5 \mathrm{ml}$ of distilled water and $0.5 \mathrm{ml}$ of $0.1 \% \mathrm{FeCl}_{3}$ solution. The solution was incubated for $10 \mathrm{~min}$ at room temperature and the absorbance was measured at $700 \mathrm{~nm}$ in a spectrophotometer. Distilled water was used as control. Higher absorbance of the reaction mixture indicated higher reducing power. 


\section{Ferric chelating ability}

The ability of hydrolysates to chelate iron (II) was assessed by the method described by (Decker and Welch, 1990).

An aliquot of $1 \mathrm{~mL}$ of each $\mathrm{CH}$ containing 1 , 2, 3, 4 and $5 \mathrm{mg}$ protein $/ \mathrm{mL}$ was first mixed with $3.7 \mathrm{~mL}$ of distilled water and then, 0.1 $\mathrm{mL}$ of $2 \mathrm{mM} \mathrm{FeCl}_{2}$ and $0.2 \mathrm{~mL}$ of $5 \mathrm{mM}$ ferrozine were added.

The reaction mixture was kept at room temperature for $20 \mathrm{~min}$. The absorbance was measured at $562 \mathrm{~nm}$ in a spectrophotometer. Distilled water was used as control. Ferric chelating activity was calculated as follows:

Ferric chelating activity $(\%)=1-($ Abs sample/Abs control) $\times 100$

\section{Hydroxyl radical scavenging activity}

Hydroxyl radical scavenging activity of hydrolysates was determined by the method described by (Smirnoff and Cumbes, 1989). An aliquot of $1 \mathrm{~mL}$ of each $\mathrm{CH}$ containing 1, 2, 3, 4 and $5 \mathrm{mg}$ protein $/ \mathrm{mL}$ was first mixed with $1.0 \mathrm{~mL}$ of $1.5 \mathrm{mM} \mathrm{FeSO}$, $0.7 \mathrm{~mL}$ of 6 $\mathrm{mM}$ hydrogen peroxide and $0.3 \mathrm{~mL}$ of $20 \mathrm{mM}$ sodium salicylate.

The reaction mixture was then incubated for 1 $\mathrm{h}$ at $37^{\circ} \mathrm{C}$ in a water bath. After incubation, the absorbance of the hydroxylated salicylate complex was measured at $562 \mathrm{~nm}$ in a spectrophotometer. Distilled water was used as control. The scavenging activity of hydroxyl radical was calculated as follows:

Hydroxyl radical scavenging activity $(\%)=1$ (Abs sample- Abs sample control) / Abs control) $\times 100$

Where, Abs sample control is absorbance without sodium salicylate.

\section{Attenuated total reflectance-Fourier transforms infrared spectroscopy (ATR- FTIR)}

ATR-FTIR spectra of each $\mathrm{CH}$ as well as collagen were determined using an iD3 ATRFTIR Spectrometer (iS5 NICOLET, Thermo Scientific, USA). $\mathrm{KBr}$ disks were first prepared with each sample in order to place onto the crystal cell and the cell was clamped into the mount of the spectrometer. The signal was collected from a range of $650-4000 \mathrm{~cm}^{-1}$ in 32 scans at a resolution of $4 \mathrm{~cm}^{-1}$ and was rationed against a background spectrum recorded from the clean empty cell at $25^{\circ} \mathrm{C}$.

\section{In vitro gastrointestinal (pepsin- pancreatin) simulated digestion}

In vitro gastrointestinal stimulated digestion was determined to assess the physiological situation in the upper gastrointestinal tract (stomach and small intestine) based on the method described by (Gil-Izquierdo et al., 2002) with slight modification. The simulated stomach solution was prepared with $3.2 \mathrm{~g}$ of pepsin, $2 \mathrm{~g}$ of $\mathrm{NaCl}$ and $7.0 \mathrm{~mL}$ of $12 \mathrm{~N} \mathrm{HCl}$ and the final $\mathrm{pH}$ was adjusted to 2.0. Aliquot of $2.5 \mathrm{~mL}$ of each $\mathrm{CH}$ containing approximately 100 to $125 \mathrm{mg} / \mathrm{mL}$ protein was added to $20 \mathrm{~mL}$ of simulated stomach solution and the $\mathrm{pH}$ was adjusted to 2.0. The mixture was incubated at $37^{\circ} \mathrm{C}$ in a shaking water bath for $2 \mathrm{~h}$. At the end of the post-gastric digestion, the mixture was immediately cooled in an ice bath and then, an aliquot of 5 $\mathrm{mL}$ was removed and taken for analysis of protein, degree of hydrolysis and antioxidant activity. A segment of cellulose dialysis tubing having a pore size of $2.4 \mathrm{~nm}$ (Himedia, Lab, Mumbai) containing $5 \mathrm{~mL}$ of $1 \mathrm{M}$ $\mathrm{NaHCO}_{3}$ solution was placed in the remaining portion of the mixture. Pancreatin solution (10 $\mathrm{mL}$ ) was prepared using $40 \mathrm{mg}$ of pancreatin, $250 \mathrm{mg}$ of bile salts and the $\mathrm{pH}$ was adjusted to 7.5 . From this, $4.5 \mathrm{~mL}$ was added to the 
mixture and incubated at $37^{\circ} \mathrm{C}$ for $2 \mathrm{~h}$. After the pancreatic digestion, the enzyme was inactivated by the addition of $6 \mathrm{~N} \mathrm{HCl}$ until $\mathrm{pH}$ 2.0. The mixture was then centrifuged at $13000 \mathrm{rpm}$ for $20 \mathrm{~min}$ at $4^{0} \mathrm{C}$ and the supernatant was collected and neutralized to $\mathrm{pH}$ 7.0. The protein content, degree of hydrolysis and DPPH radical scavenging activity of the pepsin digest, pancreatin digest and dialyzed content were determined as described earlier.

\section{Results and Discussion}

\section{Changes in the degree of hydrolysis of fish skin collagen}

The DH of fish skin collagen varied at different reaction temperature. As shown in (Fig. 1), the percentage of $\mathrm{DH}$ of $\mathrm{CH}-50$ increased to $4.27 \%$ and reached the maximum within 300 min of hydrolysis, while in $\mathrm{CH}-5$ $\mathrm{CH}-20$ and $\mathrm{CH}-25$, the hydrolysis was very gradual in the beginning and later increased to $3.9-4.2 \%$. The results indicated that the hydrolysis of collagen at higher temperature $\left(50^{\circ} \mathrm{C}\right)$ released more peptides than at lower temperatures. Several proteolytic enzymes can be employed for the hydrolysis of fish protein such as trypsin, pepsin, papain, alcalase, flavourzyme, and bromelain (Ghanbari et al., 2012).

The enzyme, papain used for hydrolysis is a cysteine protease that breaks peptide bonds involving the use of a catalytic triad (HisAsn-Cys) with a deprotonated cysteine to cleave basic aminoacids (arginine and lysine) and hydrophobic aminoacids (leucine and glycine) (Paul and Leemor, 2007). The type of enzyme and substrate are known to influence the DH. Fan et al., indicated that much higher $\mathrm{DH}$ of $13.8,15.1$ and $12.7 \%$ could be achieved using properase E, pepsin, trypsin and flavourenzyme, respectively than other proteolytic enzymes (Fan et al., 2012).
A maximum DH of $15 \%$ could be achieved with the commercial proteolytic enzymes of plant and animal origin. Microbial enzymes possess excellent activities on specific substrates and however their commercial production on large scale is still in a preliminary stage. As papain is readily available commercially at low cost, the same has been employed in this study to examine the $\mathrm{DH}$ of the unicorn leatherjacket fish skin.

Fish collagen, in general, possesses lower denaturation temperatures than that of animal collagen. The denaturation temperature of fish collagen varies with the fish species, their habitat and method of extraction (Muralidharan et al., 2013). Tropical fish collagen possesses higher denaturation temperature $\left(27-34^{\circ} \mathrm{C}\right)$ than that of temperate fish collagen $\left(16-20^{\circ} \mathrm{C}\right)$ (Ogawa, 2004). As the unicorn leatherjacket fish is a tropical fish, the skin collagen from it had an average denaturation temperature of $28^{\circ} \mathrm{C}$ (data not given). The collagen hydrolysates are produced through the breakage of corresponding peptide bonds in the 3dimensional collagen network by specific proteases at their cleavage sites. With the increase in the hydrolysis temperature, the collagen strands begin to denature (uncoil) through breakage of intra-molecular and intermolecular hydrogen bonds in the $\alpha$-helix strands, and later hydrolyzed by the proteinases to yield much smaller peptides, as in the case of $\mathrm{CH}-50$. Commercially, collagen hydrolysates are produced by treating the fish skin at higher temperatures $\left(50^{\circ} \mathrm{C}\right)$ followed by hydrolysis using proteases.

The application of low temperatures $\left(5^{0} \mathrm{C}\right.$ $25^{\circ} \mathrm{C}$ ) for hydrolysis is therefore expected to yield collagen peptides with different conformation due to the inheritance of intra and inter molecular hydrogen bonds and other electrostatic interactions that provide more biofunctional properties. 
Antioxidative activities of collagen hydrolysates

The antioxidative properties of $\mathrm{CH}$ prepared at four different hydrolysis temperatures are shown in (Fig. 2). The average DPPH radical scavenging activity of $\mathrm{CH}-5$ was $69 \%$ at 12 $\mathrm{mg} / \mathrm{mL}$ protein concentration $(\mathrm{p}<0.05)$ but those of $\mathrm{CH}-20, \mathrm{CH}-25$ and $\mathrm{CH}-50$ were slightly lower with the corresponding increase in hydrolysis temperatures. Dose dependent activities were recorded with the increase in the concentration of all the hydrolysates from 2 to $14 \mathrm{mg} / \mathrm{mL}$ protein concentration. The relative $\mathrm{IC}_{50}$ values of unicorn leatherjacket fish skin collagen hydrolysates viz. CH-5, $\mathrm{CH}-20, \mathrm{CH}-25$ and $\mathrm{CH}-50$ were recorded as $8,7.5,7.5$ and $7 \mathrm{mg} / \mathrm{mL}$, respectively. Earlier, (Fan et al., 2012) have reported an $\mathrm{IC}_{50}$ value $1.92 \mathrm{mg} / \mathrm{mL}$ for tilapia frame protein hydrolysates probably because of the use of the trypsin enzyme, which had yielded different bioactive peptides.

The average ferric chelating activity in $\mathrm{CH}-5$ was much higher than the other hydrolysates (Fig. 3). A maximum ferric chelating activity of $33 \%$ at $8 \mathrm{mg} / \mathrm{mL}$ protein concentration was recorded in $\mathrm{CH}-5$.

The activity exhibited by $\mathrm{CH}-50$ was lesser than that of other hydrolysates. Previous studies on the ferric chelating properties of $\mathrm{CH}$ are very limited. $\mathrm{Fe}^{2+}$ and $\mathrm{Cu}^{2+}$ are the two major metal pro-oxidants that induce oxidation. Metal chelating properties are examined to study the effect of biomolecules in chelating either of these two metal ions. A study that investigated the $\mathrm{Cu}^{2}$ chelating activity of jellyfish collagen hydrolysates and their fractions indicated that fraction 2 having 3KDa molecular size exhibited the highest activity of $56.5 \%$ at $0.5 \mathrm{mg} / \mathrm{mL}$; while those above $>3 \mathrm{KDa}$ molecular size showed only $31.7 \%$ activity (Zhuang et al., 2009). As the unicorn leatherjacket fish skin collagen hydrolysates contained peptides of varying molecular sizes, the $\mathrm{Fe}^{2+}$ chelating activity expressed was quite low. The relative $\mathrm{IC}_{50}$ values of $\mathrm{CH}-5, \mathrm{CH}-20, \mathrm{CH}-25$ and $\mathrm{CH}-50$ for $\mathrm{Fe}^{2+}$ chelating activity were recorded as 5 , 4,4 , and $3.5 \mathrm{mg} / \mathrm{mL}$, respectively.

The ferric reducing ability of plasma (FRAP) of $\mathrm{CH}-5$ showed good activity with an average absorbance value of 0.32 at $8 \mathrm{mg} / \mathrm{mL}$ protein concentration (Fig. 4) than that of other hydrolysates. Temperature dependent activities were recorded for DPPH radical scavenging, ferric chelating and ferric reducing property of the $\mathrm{CH}$.

The role of different proteinases enzymes in expressing the reducing ability of the resultant hydrolysates is therefore different. Papain produces hydrolysates with higher ferric reducing ability than bromelain. The relative $\mathrm{IC}_{50}$ values of $\mathrm{CH}-5, \mathrm{CH}-20, \mathrm{CH}-25$ and $\mathrm{CH}-$ 50 for the ferric reducing ability of plasma were $5,4.5,4.5$ and $4.5 \mathrm{mg} / \mathrm{mL}$, respectively.

The average hydroxyl radical scavenging activities of the $\mathrm{CH}$ were more or less similar, irrespective of the reaction temperatures (Fig. 5). At the protein concentration of $10 \mathrm{mg} / \mathrm{mL}$, the average activities recorded were around $59 \%$. Only at higher protein concentration, there was a slight decrease in the activities of $\mathrm{CH}-50$ as compared to other hydrolysates. The relative $\mathrm{IC}_{50}$ values of $\mathrm{CH}-5, \mathrm{CH}-20, \mathrm{CH}-$ 25 and $\mathrm{CH}-50$ were recorded as 10, 7, 7 and $6.5 \mathrm{mg} / \mathrm{mL}$, respectively. Fan et al., reported that tilapia frame protein was hydrolyzed by different proteases, including properase $\mathrm{E}$, pepsin, trypsin, flavourzyme, neutrase, gc106 and papain, to obtain three series of peptides (TFPH1, TFPH 2 and TFPH 3) by ultrafiltration through molecular weight cutoff membranes of 5,3 and $1 \mathrm{kDa}$, respectively; and TFPH1 showed the highest hydroxyl radical scavenging activities with an $\mathrm{IC}_{50}$ value of $0.98 \mathrm{mg} / \mathrm{mL}$ (Fan et al., 2012). 
Attenuated total reflectance-fourier transforms infrared spectroscopy (ATRFTIR)

In order to examine the difference in the structural conformation, the FTIR spectra of the different $\mathrm{CH}$ were analysed as shown in (Fig. 6). Fish collagen typically possessed five peaks viz. amide A $\left(3431 \mathrm{~cm}^{-1}\right)$, amide B (2923 $\left.\mathrm{cm}^{-1}\right)$, amide I $\left(1641 \mathrm{~cm}^{-1}\right)$, amide II $\left(1549 \mathrm{~cm}^{-1}\right)$ and amide III $1240\left(\mathrm{~cm}^{-1}\right)$ due to their helical arrangements as reported earlier (Plepis et al., 1996; Zhang et al., 2014). As for $\mathrm{CH}$, there were minor changes after hydrolysis in the positions of peaks. Amide B and amide III peaks were not detected in any of the $\mathrm{CH}$ obtained after papain digestion. This indicates that part of the collagen helical arrangements was destroyed or might be remaining in the unhydrolysed fraction.

Disappearance of amide III and a peak at $1456 \mathrm{~cm}^{-1}$ is an indication of the disappearance of triple helical structure (Plepis et al., 1996). Amide III peak represents the combination peak between $\mathrm{C}-\mathrm{N}$ stretching and $\mathrm{N}-\mathrm{H}$ deformation from amide linkage as well as absorption arising from wagging vibrations from $\mathrm{CH}_{2}$ groups of the glycine backbone and protein side changes.
The peak at $1454 \mathrm{~cm}^{-1}$ corresponds to the existence of a $\mathrm{CH}$ bending vibration. The disappearance of helical structure after pepsin and trypsin hydrolysis of collagen was also reported earlier by few workers (Chi et al., 2014).

Among the $\mathrm{CH}$, no major modifications were noticed in amide A $\left(3432 \mathrm{~cm}^{-1}\right)$ except that a small shift was observed in CH-5 $\left(3426 \mathrm{~cm}^{-1}\right)$. The peak at the wave number $2360 \mathrm{~cm}^{-1}$ remained unchanged in all the hydrolysates, while the peak at $2341 \mathrm{~cm}^{-1}$ was not detected in $\mathrm{CH}-5$. The peak at $2341 \mathrm{~cm}^{-1}$ was unique in $\mathrm{CH}$, except $\mathrm{CH}-5$ mainly corresponding to the $\mathrm{C}-\mathrm{H}$ vibrations due to triple bonds. A peak at $2245 \mathrm{~cm}^{-1}$ was noticed only in $\mathrm{CH}-50$. In respect of amide I peak corresponding to $\mathrm{C}=\mathrm{O}$ stretching, there was a positive shift noticed only in CH-5 $\left(1644 \mathrm{~cm}^{-1}\right)$. Amide II peak at $1560 \mathrm{~cm}^{-1}$ corresponding to $\mathrm{C}-\mathrm{N}$ stretching and $\mathrm{N}-\mathrm{H}$ bending also exerted a small shift in $\mathrm{CH}-5$ and $\mathrm{CH}-25$. The peak at $1412 \mathrm{~cm}^{-1}$ also showed minor changes in $\mathrm{CH}-5$ and $\mathrm{CH}-25$. Another peak at $1339 \mathrm{~cm}^{-1}$ indicating the presence of nitro compounds $(\mathrm{N}-\mathrm{O})$ showed a shift in CH-5 $\left(1343 \mathrm{~cm}^{-1}\right)$. The peaks corresponding to the presence of alcohol, ether, ester etc with $\mathrm{C}-\mathrm{O}$ were noticed in all the hydrolysates.

Fig.1 Degree of hydrolysis of collagen hydrolysates of unicorn leatherjacket skin prepared using papain enzyme

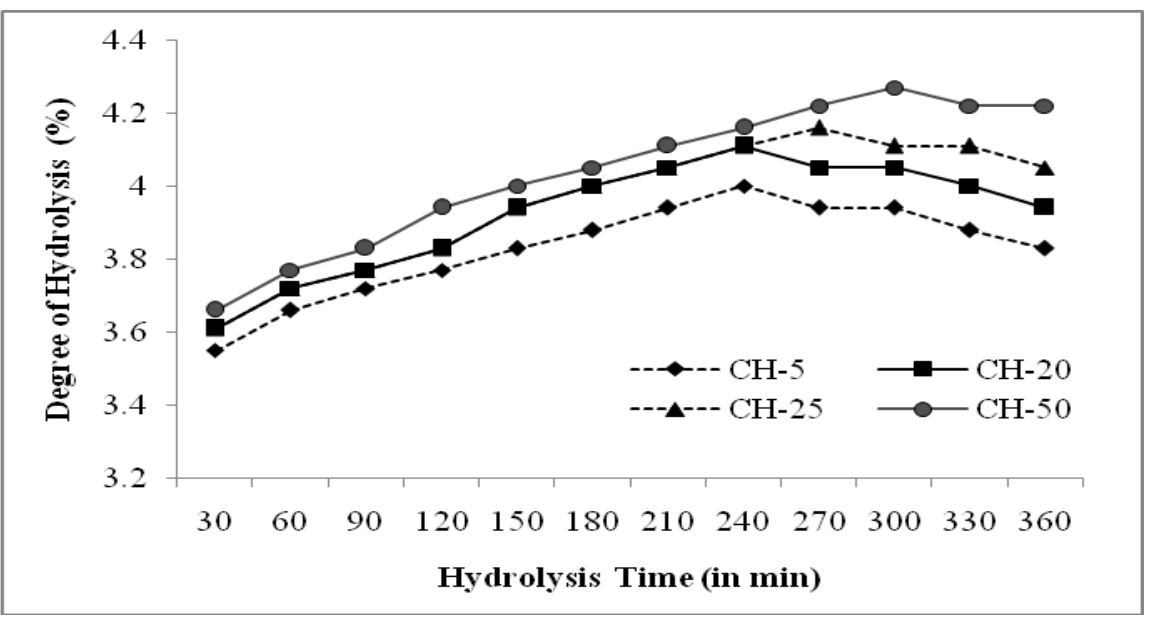


Fig.2 DPPH radical scavenging activities of unicorn leatherjacket skin collagen hydrolysates

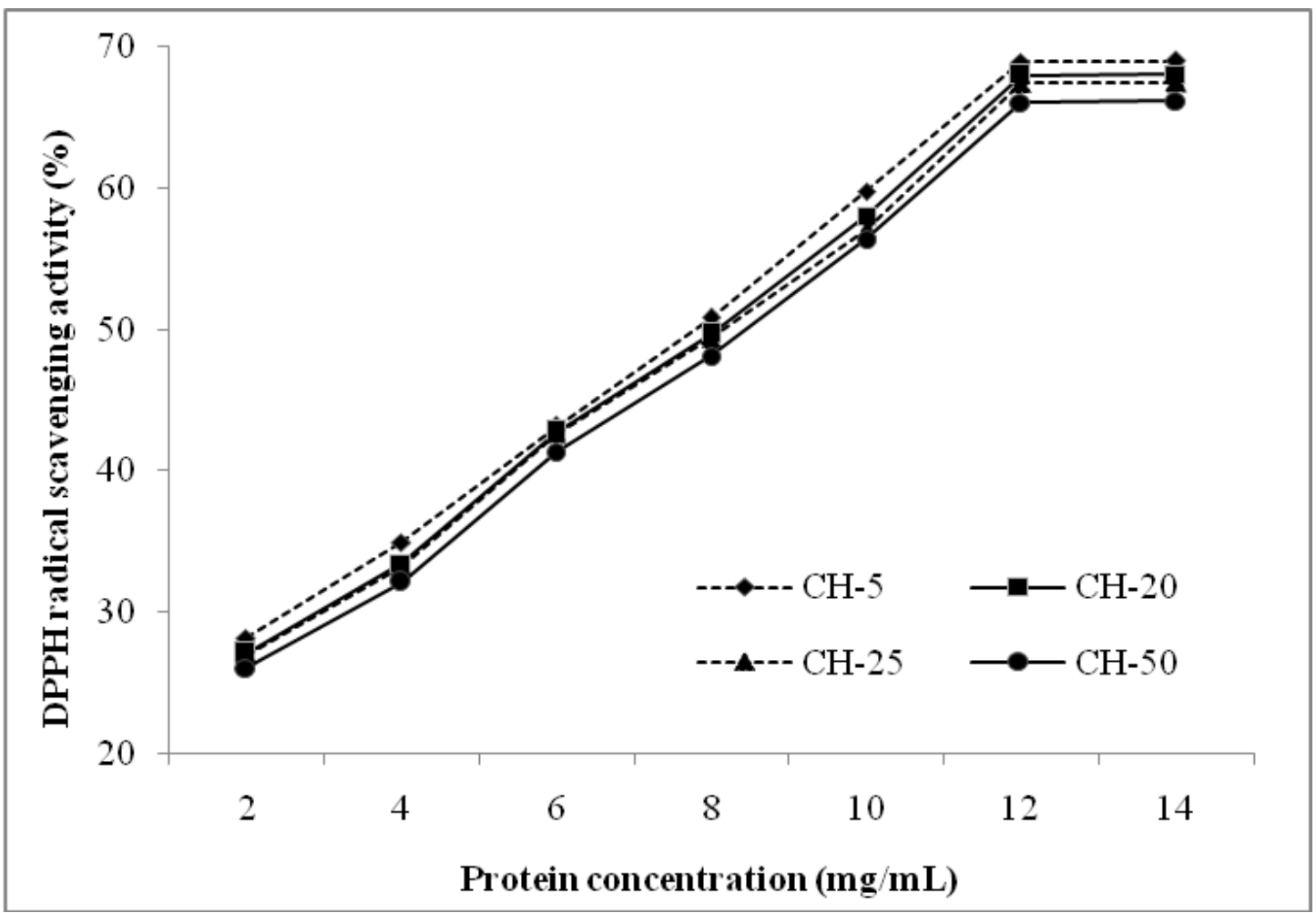

Fig.3 Ferric chelating activities of unicorn leatherjacket skin collagen hydrolysates

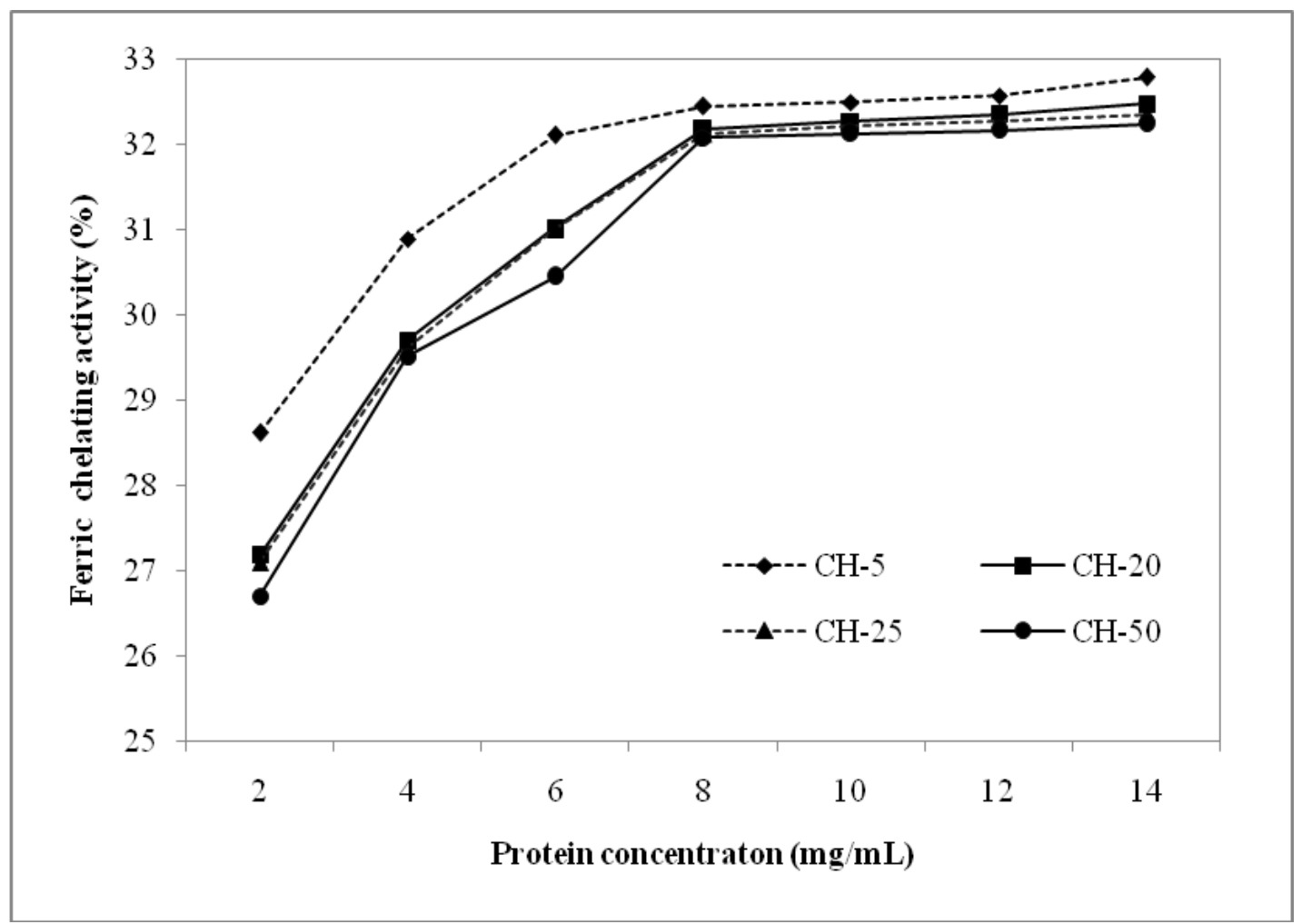


Fig.4 Ferric reducing ability of unicorn leatherjacket skin collagen hydrolysates

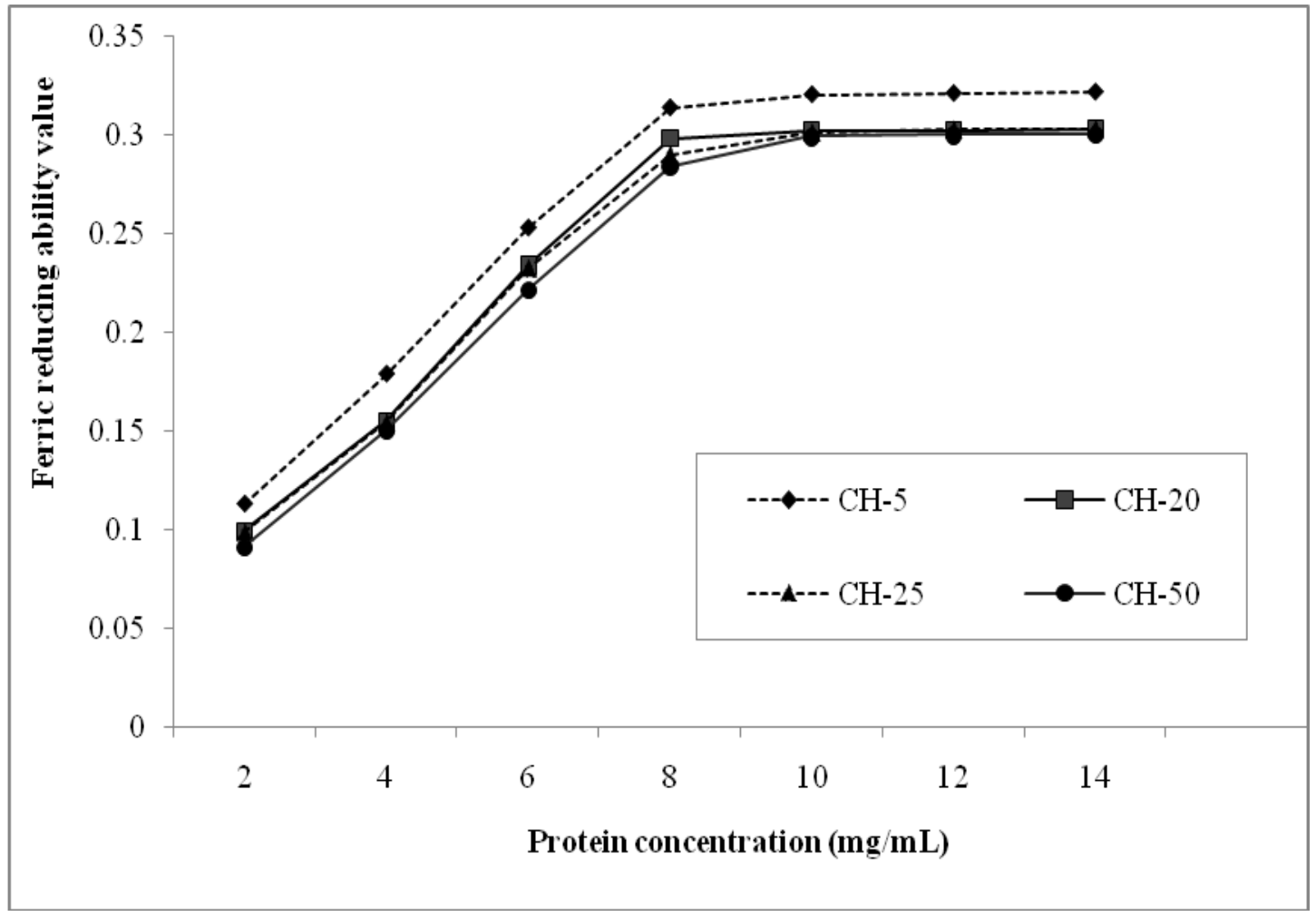

Fig.5 Hydroxy radical scavenging activities of unicorn leatherjacket skin collagen hydrolysates

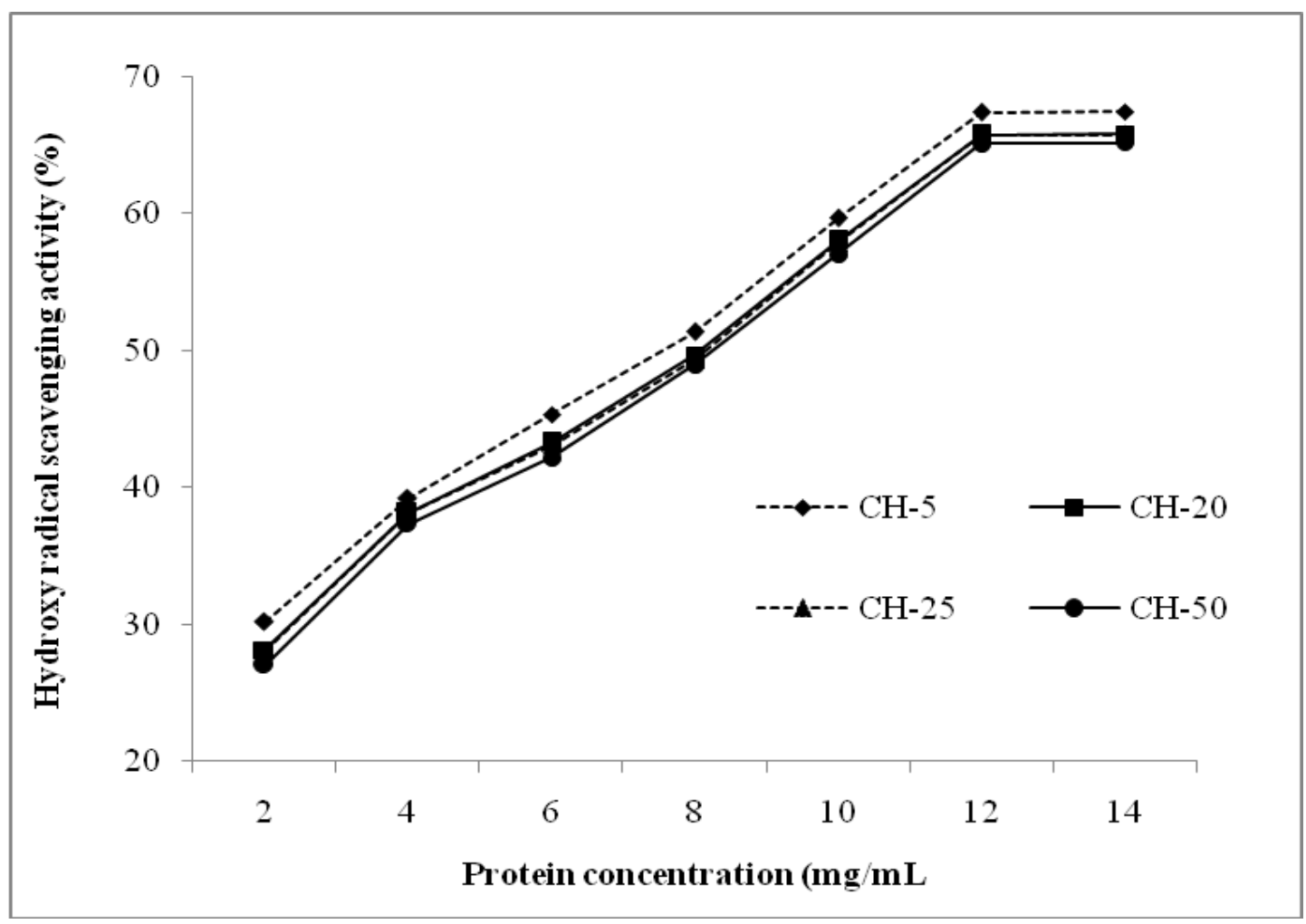


Fig.6 Attenuated total reflectance-Fourier transforms infrared spectroscopy of collagen and collagen hydrolysates of unicorn leatherjacket skin

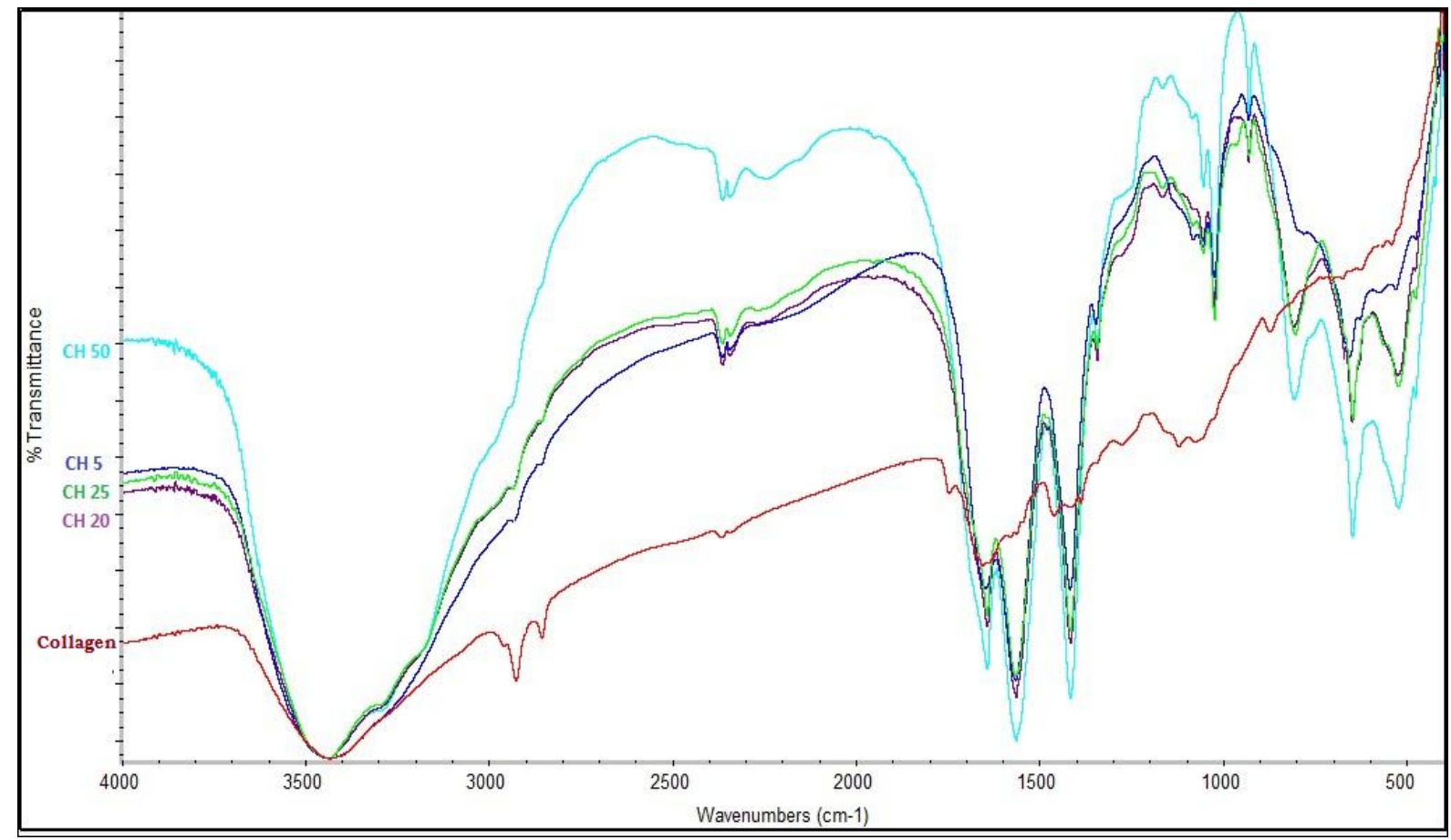

Fig.7 In-vitro gastro intestinal digestion of unicorn leatherjacket skin collagen hydrolysates

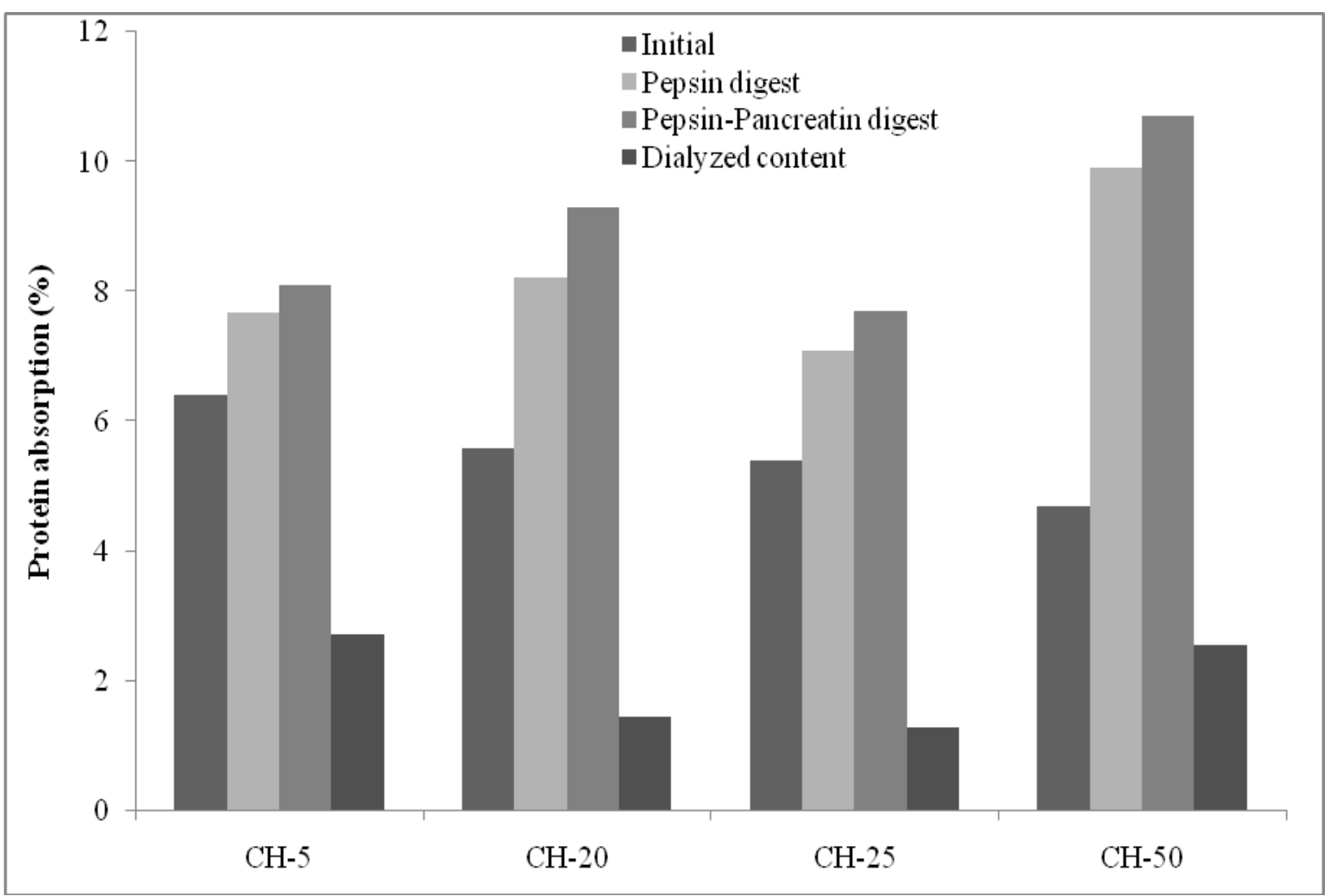


Fig.8 Degree of hydrolysis of in-vitro gastro intestinal digestion of unicorn leatherjacket skin collagen hydrolysates

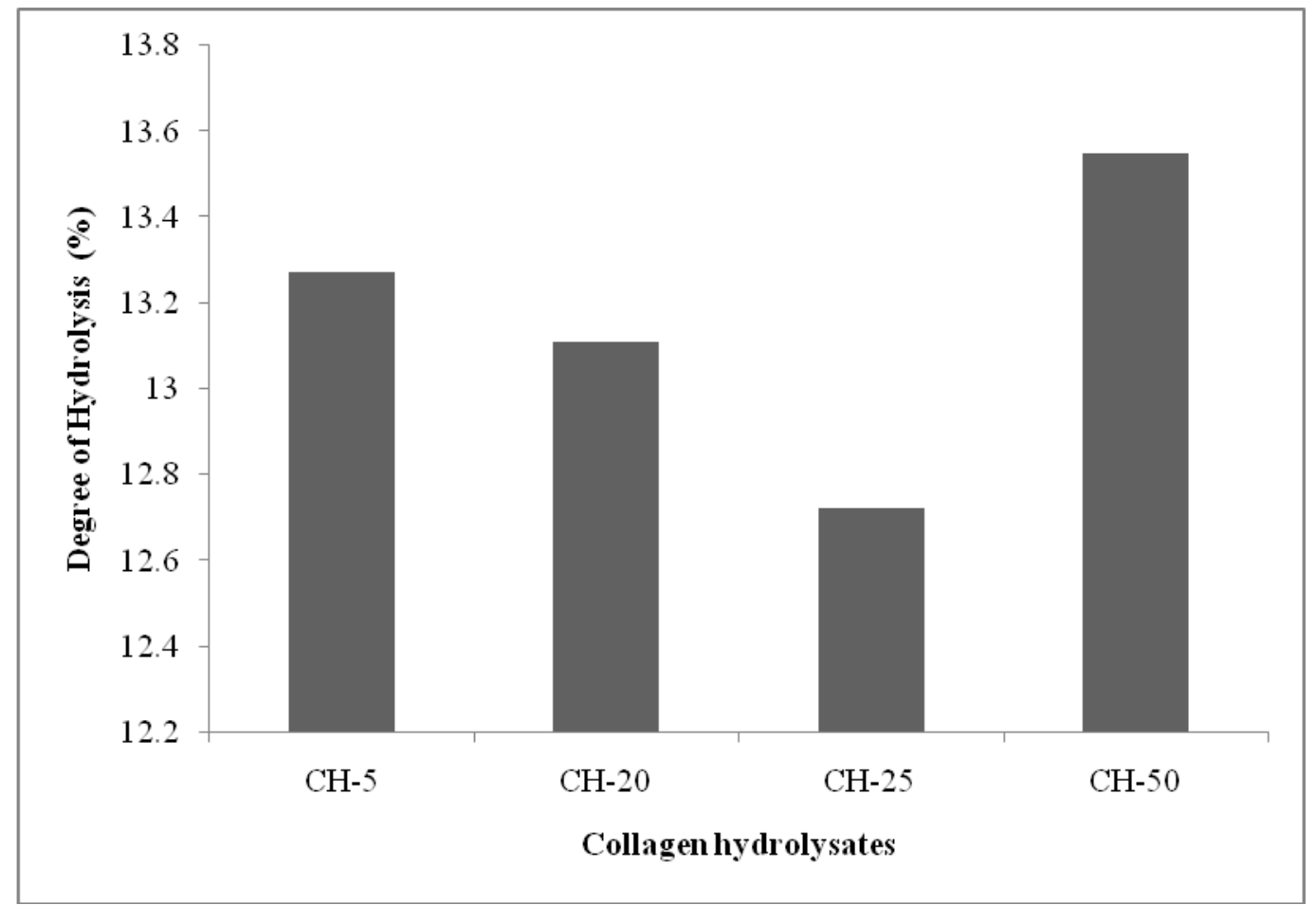

Fig.9 DPPH radical scavenging activity of in-vitro gastro intestinal digestion of unicorn leatherjacket skin collagen hydrolysates

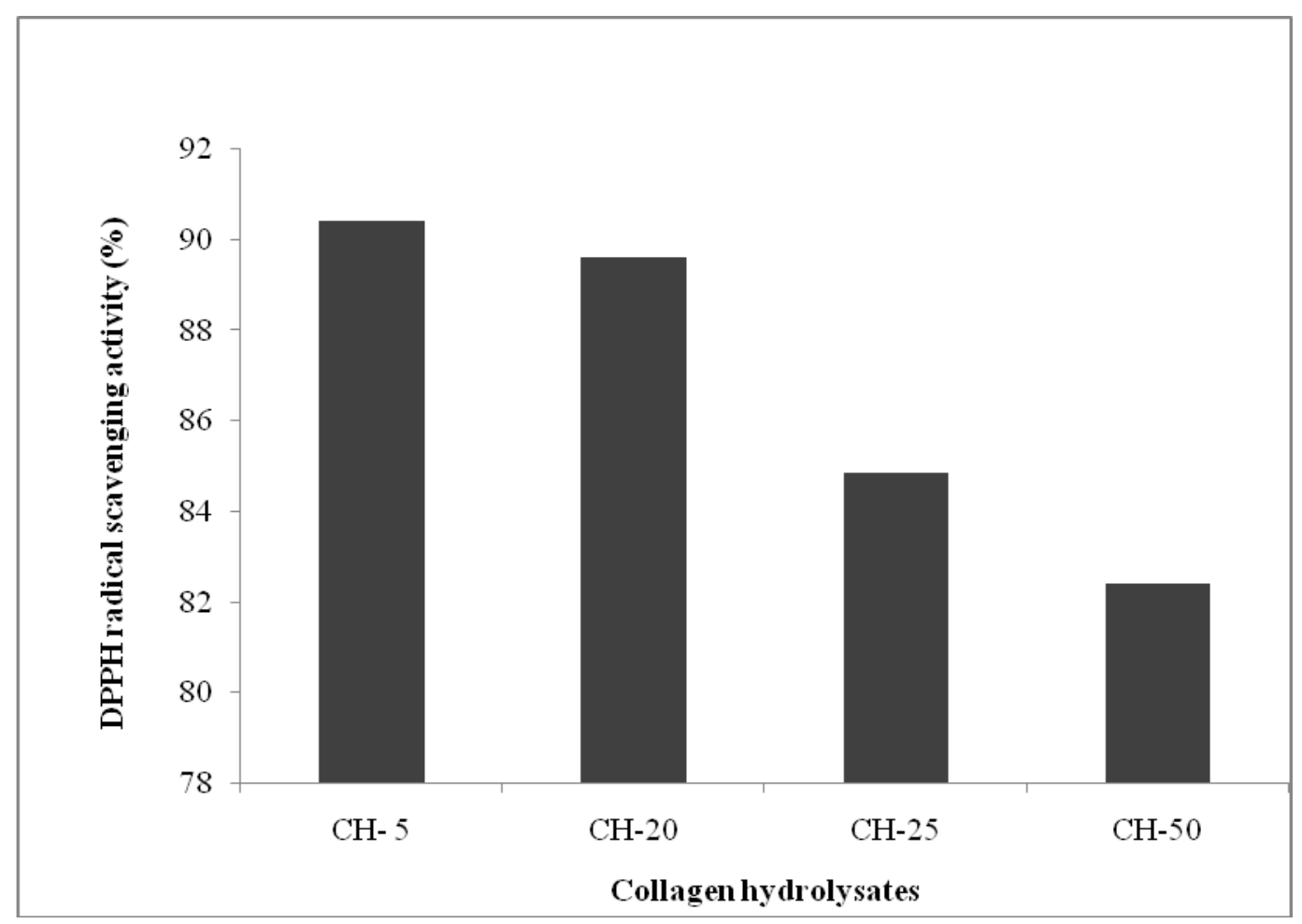


Presence of aromatic rings as indicated by C$\mathrm{H}$ peaks was detected at $803 \mathrm{~cm}^{-1}$ in all the hydrolysates but not in CH-5. Similarly, bromoalkanes $(\mathrm{C}-\mathrm{Br})$ peak at wavenumber $520 \mathrm{~cm}^{-1}$ was not present in $\mathrm{CH}-5$ and $\mathrm{CH}-20$; however, chloroalkanes $(\mathrm{C}-\mathrm{Cl})$ peak at 645 $\mathrm{cm}^{-1}$ was found in all the hydrolysates. The shift noticed in many of the functional groups of $\mathrm{CH}-5$ distinguished it from other hydrolysates. Correspondingly, the presence of an additional peak at $2245 \mathrm{~cm}^{-1}$ is typical for $\mathrm{CH}-50$ indicating their derivatization from gelatin and not collagen. This peak corresponds to $\mathrm{C}=\mathrm{C}$ alkanes as well as $\mathrm{C}=\mathrm{N}$ nitriles groups in the respective molecule.

\section{In-vitro gastro intestinal digestion of collagen hydrolysates}

Changes in the protein concentration of pepsin and pepsin-pancreatin digests; as well as dialysed extract following in-vitro gastrointestinal digestion of $\mathrm{CH}$ are shown in (Fig. 7). The protein concentration of $\mathrm{CH}$ varied between 4.7 to $6.4 \mathrm{mg} / \mathrm{mL}$ in the digestion solution. It increased in the pepsin digest of the hydrolysates due to the incorporation of enzymes, pepsin and pancreatin proportionately in the digestion solution. The absorption of the protein through the dialysis membrane was also estimated in the dialyzed content to examine the rate of absorption of peptides. As shown in Figure 6, the rate of peptide absorption of the $\mathrm{CH}$ was significantly high in $\mathrm{CH}-50$ $(54.25 \%)$ after gastric and pancreatin digestion. The average rate of absorption of collagen peptides from $\mathrm{CH}-5$ was $42.5 \%$, while from $\mathrm{CH}-20$ and $\mathrm{CH}-25$, it was only $25.89 \%$ and $24.07 \%$, respectively. As the temperature increased, the rate of absorption subjected to gastric and pancreatic digestion decreased in the collagen peptides hydrolysed at low temperatures. Collagen being a connective tissue protein is not completely digested by the gastric and pancreatin enzymes; and hence the absorption of collagen peptides was quite limited. The higher rate of absorption of $\mathrm{CH}-50$ peptides was probably because of the partial denaturation of intact collagen strands into gelatin at $50^{\circ} \mathrm{C}$ and subsequent hydrolysis by proteinases yielding more denatured form of peptides, as noticed through IR spectral analysis.

\section{Degree of hydrolysis of in vitro gastro intestinal digests}

$\mathrm{DH}$ of the $\mathrm{CH}$ in the corresponding digests are shown in (Fig. 8). The average DH was significantly more in $\mathrm{CH}-50, \mathrm{CH}-5, \mathrm{CH}-20$ and $\mathrm{CH}-25$. After pepsin digestion, the average $\mathrm{DH}$ activities increased in $\mathrm{CH}-50$, $\mathrm{CH}-5, \mathrm{CH}-20$, and $\mathrm{CH}-25$ in accordance with the pepsin-induced hydrolysis. When the pepsin digest was further hydrolysed with pancreatin, the average DH further increased in all the hydrolysates. In order to examine the biological property of the absorbed peptides of the different collagen hydrolysates, the free amino groups in the dialyzed content was estimated. The free amino groups in the bioaccessible collagen peptides as compared to the pancreatin digest were calculated and the results are shown in Figure 8. The percentage absorption of collagen peptides ranged between 12-14\%. The free amino groups absorption was higher for $\mathrm{CH}-50$, followed by $\mathrm{CH}-5, \mathrm{CH}-20$ and CH-25.

\section{DPPH radical scavenging activity of in vitro gastro intestinal digests}

The DPPH radical scavenging activities of the $\mathrm{CH}$ in the corresponding digests are shown in (Fig. 9). The average DPPH radical scavenging activity was significantly higher in the $\mathrm{CH}-5, \mathrm{CH}-20$ and $\mathrm{CH}-25$ than that of $\mathrm{CH}-50$. After pepsin digestion, the average DPPH radical scavenging activities increased 
in the order of CH-5, CH-20, $\mathrm{CH}-25$ and $\mathrm{CH}-$ 50. When the pepsin digest are further hydrolysed with pancreatin, the average DPPH radical scavenging activity increased only at a marginal rate. As the $\mathrm{CH}$ are derived using commercial papain, the gastric pancreatin digestion did not hydrolyze the substrate further, which could to the reason for the marginal increase in the protein as well as the antioxidant activity in the corresponding pancreatin digests.

In order to examine the biological property of the absorbed peptides of the different $\mathrm{CH}$, the DPPH radical scavenging activity in the dialyzed content was estimated. Interestingly, it was noted that the average DPPH radical scavenging activities of the dialyzed content of $\mathrm{CH}$ decreased significantly than that of the pancreatin digests. The retention of the activity in the bioaccessible collagen peptides as compared to the pancreatin digest was calculated and the results are shown in Figure 8 . The percentage retention of activity after the absorption of collagen peptides ranged between $82-90 \%$. The percentage retention of activity was more for $\mathrm{CH}-5$, followed by $\mathrm{CH}-$ 20 and $\mathrm{CH}-25$ and $\mathrm{CH}-50$. Eventhough the rate of absorption of peptides was more in $\mathrm{CH}-50$, the DPPH activity expressed was less.

The results indicated that although small proportion of $\mathrm{CH}-5$ were bioaccessible, they exhibited good antioxidative property. The $\mathrm{CH}-50$, on the other hand, was highly bioaccessible, but did not exhibit good antioxidative activity. This clearly emphasis that peptides present in the $\mathrm{CH}-5$ possessed more bioactivity than those available in the $\mathrm{CH}-50$. The bioactivity of the collagen peptides is more related to the retention of their 3-dimensional molecular conformation that determines the physical, chemical and biological activities of the molecules. FTIR spectral analysis corresponds with it showing shift to lower wave number in major amide A, amide I and amide II peaks as well as causing shift towards higher wave number in $\mathrm{N}-\mathrm{O}$ nitroso compounds peak at $1340 \mathrm{~cm}^{-1}$ and C$\mathrm{Cl}$ chloroalkane peak at $645 \mathrm{~cm}^{-1}$. Disappearance of aromatic rings at $803 \mathrm{~cm}^{-1}$ and bromoalkanes peak at $519 \mathrm{~cm}^{-1}$ in $\mathrm{CH}-5$ provided a different conformational structure possessing more bioactivity even though bioaccessibility was comparatively low.

Although there were no studies on the antioxidative activity on the assessment of fish collagen hydrolysates following in-vitro gastro intestinal digestion. Three different squid skin peptide fractions of different molecular sizes, viz. 10-3KDa, 3-1KDa and $<1 \mathrm{KDa}$ obtained through hydrolysis by esperase enzyme for the ACE inhibitory activity following simulated in vitro gastrointestinal digestion and found that digestion with pepsin followed by pancreatin gave an increase in low molecular weight peptides contributing to high tissue affinity and slow elimination rate ACE inhibitory activity (2). Further study is however essential to isolate the small molecular weight collagen peptides following ultrafiltration and to examine their bioaccessibility after gastric and pancreatic digestion to ascertain their biological activity, which shall provide much more detailed information on the bioaccessibility of small collagen peptides following pepsin and pancreatin digestion; and subsequent biological activity.

The results indicated that the hydrolysis of unicorn leatherjacket skin at different temperatures using papain collagen hydrolysates with different antioxidant properties. Although the degree of hydrolysis was more at $50^{\circ} \mathrm{C}$, collagen hydrolysates produced at $5^{0} \mathrm{C}$ gave marginally good antioxidant properties, particularly in terms of ferric reducing and ferric chelating properties. Subsequent study proved good bioaccessibility of collagen hydrolysates 
produced at $50^{\circ} \mathrm{C}$, but those produced at $5^{\circ} \mathrm{C}$ only expressed excellent bioactivity. Hence, it is recommended to produce collagen hydrolysates from fish skin wastes at low temperatures rather than at $50^{\circ} \mathrm{C}$ to retain good biological properties.

\section{Acknowledgements}

The authors thank to the Head of the Department of Fish Quality Assurance and Management, Tamil Nadu Fisheries University, Fisheries College and Research Institute, Tuticorin for his encouragement and for providing the necessary facilities to undertake this work.

\section{References}

Adler-Nissen, J. 1979. Determination of the degree of hydrolysis of food protein hydrolysates by trinitrobenzenesulfonic acid. Agric. Food. Chem. 27: 12561262

Alemán, A., Gómez-Guillén, M.C., and Montero, P. 2013. Identification of aceinhibitory peptides from squid skin collagen after in vitro gastrointestinal digestion. Food. Res. Int. 54:790-795.

Chi, C.F., Cao, Z.H., Wang, B., Hu, F.Y., Li, Z.R., and Zhang, B. 2014. Antioxidant and functional properties of collagen hydrolysates from Spanish mackerel skin as influenced by average molecular weight. Mole. 19: 11211-11230.

Decker, E.A., and Welch, B. 1990. Role of ferritin as a lipid oxidation catalyst in muscle food. J. Agr. Food. Chem. 38: 674-677.

Fan, J., He, J., Zhuang, Y., and Sun, L. 2012. Purification and identification of antioxidant peptides from enzymatic hydrolysates of tilapia (Oreochromis niloticus) frame protein. Mole. 17: 12836-12850.
Ghanbari, R., Ebrahimpour, A., AbdulHamid, A., Ismail, A., and Saari, N. 2012. Actinopyga lecanora hydrolysates as natural antibacterial agents. Int. J. Mol. Sci. 13: 16796-16811.

Gil-Izquierdo, A., Zafrilla, P., and Tomásbarberán, F. 2002. An in vitro method to simulate phenolic compound release from the food matrix in the gastrointestinal tract. Eur. Food. Res. Tech. 214: 155-159.

Gomez-Guillen, M.C., Turnay, J., FernandezDiaz, M.D., Ulmo, N., Lizarbe, M.A., and Montero, P. 2002. Physical properties of gelatin extracted from different marine species: a comparative study. Food. Hydrocoll. 16: 25-34.

Lee, C.H., Singla, A., and Lee, Y. 2001. Biomedical applications of collagen. Int. J. Pharm. 221: 1-22.

Montero, P., Alvarez, C., Marti, M.A., and Borderias, A.J. 1995. Plaice skin collagen extraction and functional properties. J. Food. Sci. 60: 1-3.

Muralidharan, N., Jeya Shakila, R., Sukumar, D., and Jeyasekaran, G. 2013. Skin, bone and muscle collagen extraction from the trash fish, leatherjacket (Odonus niger) and their characterization. J. Food. Sci. Technol. 50: 1106-1113.

Ogawa, M., Portier, R.J., Moody, M.W., Bell, J., Schexnayder, M.A., and Losso, J.N. 2004. Biochemical properties of bone and scale collagens isolated from the subtropical fish black drum (Pogonia cromis) and sheepshead seabream (Archosargus probatocepahlus). Food.Chem. 88: 495-501.

Oyaizu, M. 1986. Studies on products of the browning reaction: Antioxidative activities of browning reaction products prepared from glucosamine. Jpn. J. Nutr. 44: 307-315.

Paul, A., and Leemor, J.T. 2007. Mutagenesis and crystallographic studies of the 
catalytic residues of the papain family protease bleomycin hydrolase: new insights into active-site structure. Biochem. J. 401: 421-428.

Plepis, A.M., Goissis, G., and Das-Gupta, D.K. 1996. Dielectric and pyroelectric characterization of anionic and native collagen. Polym. Eng. Sci. 36: 29322938.

Sato, K.., Yoshinaka, R., Sato, M., and Ikeda, S. 1986. A simplified method for determining collagen in fish muscle. Bull Jpn. Soc. Sci. Fisheries. 52: 889893.

Smirnoff, N., and Cumbes, Q.J. 1989. Hydroxyl radical scavenging activity of compatible solutes. Phytochem. 28: 1057-1060.

Wang, B., Wang, Y.M., Chi. C.F., Luo. H.Y., Deng. S.G., and Ma. J.Y. 2013.
Isolation and characterization of collagen and antioxidant collagen peptide from scales of Croceine croaker (Pseudosciaena crocea). Mar. Drugs. 11: 4641-4661.

Yen, G.C., and Wu, J.Y. 1999. Antioxidant and radical scavenging properties of extract from Ganoderma tsugae. Food Chem. 65: 375-379.

Zhang, J., Duan, R., Huang, L., Song, Y., and Regenstein, J.M. 2014. Characterisation of acid-soluble and pepsin-solubilised collagen from jellyfish (Cyanea nozakii Kishinouye). Food Chem. 150: 22-26.

Zhuang, Y.L., Zhao, X., and Li, B.F. 2009. Optimization of antioxidant activity by response surface methodology in hydrolysates of jellyfish (Rhopilema esculentum) umbrella collagen. J. Zhejiang. Univ. Sci. B. 10: 572-579.

\section{How to cite this article:}

Vinoth Kumar Lakshmanan, Jeya Shakila Robinson, Jeyasekaran Geevaretnam, Velayutham Padmanaban and Wenhui Wu. 2018. Effect of Hydrolysis Temperature on in vitro Bioaccessibility and Antioxidant Properties of Unicorn Leather Jacket (Aluterus monoceros) Skin Collagen Hydrolysates Following Simulated Gastro-Intestinal Digestion. Int.J.Curr.Microbiol.App.Sci. 7(03): 3531-3545. doi: https://doi.org/10.20546/ijcmas.2018.703.406 